\title{
Magnesium-Palm Kernel Shell Biochar Composite for Effective Methylene Blue Removal: Optimization via Response Surface Methodology
}

\author{
Nur Hanani Hasana ${ }^{1}$, Rafeah Wahi ${ }^{1 *}$, Yusralina Yusof ${ }^{1}$ and \\ Nabisab Mujawar Mubarak ${ }^{2}$ \\ ${ }^{1}$ Faculty of Resource Science and Technology, Universiti Malaysia Sarawak, 94300 UniMAS, \\ Kota Samarahan, Sarawak, Malaysia \\ ${ }^{2}$ Department of Chemical and Energy Engineering, Faculty of Engineering and Science, Curtin University, \\ 98009 Miri, Sarawak, Malaysia
}

\begin{abstract}
This study investigates the properties and potential application of Mg-PKS biochar composite for methylene blue solution (MB) adsorption. The Mg-PKS biochar composite was developed from palm kernel shell biochar via steam activation followed by $\mathrm{MgSO}_{4}$ treatment and carbonization. The effect of process parameters such as solution $\mathrm{pH}$ (4-10), contact time (30-90 $\mathrm{min})$ and adsorbent dosage (0.1-0.5 g) were investigated via central composite design, response surface methodology. Results revealed that the Mg-PKS biochar composite has irregular shapes pore structure from SEM analysis, a surface area of $674 \mathrm{~m}^{2} \mathrm{~g}^{-1}$ and average pore diameters of $7.2195 \mu \mathrm{m}$ based on BET analysis. RSM results showed that the optimum adsorption of MB onto Mg-biochar composite was at $\mathrm{pH} 10$, 30 min contact time and $0.5 \mathrm{~g} / 100 \mathrm{~mL}$ dosage with a removal efficiency of $98.50 \%$. In conclusion, $\mathrm{Mg}$ treatment is a potential alternative to other expensive chemical treatment methods for biochar upgrading to the adsorbent.
\end{abstract}

ARTICLE INFO

Article history:

Received: 02 February 2021

Accepted: 16 April 2021

Published: 31 July 2021

DOI: https://doi.org/10.47836/pjst.29.3.28

E-mail addresses:

nurhananihasana@gmail.com (Nur Hanani Hasana)

wrafeah@unimas.my (Rafeah Wahi)

yyusralina@unimas.my (Yusralina Yusof)

mubarak.mujawar@curtin.edu.my (Nabisab Mujawar Mubarak)

* Corresponding author
Keywords: Adsorption, magnesium treatment, methylene blue, palm kernel shell biochar, response surface methodology

\section{INTRODUCTION}

Methylene blue (MB) is a common basic dye applied in paper colouring, hair dye, cotton dyeing and others (Ba et al., 2020). Methylene blue was also studied for medical uses, including antimicrobial chemotherapy, 
biomedical colouring for cell staining, phototherapy and cancer research (Sahu et al., 2020). However, exposure to MB at high concentration can affect human health, for example, difficulty in breathing, retching, nausea, gastritis, and diarrhoea (Sahu et al., 2020). At doses greater than $7.0 \mathrm{mg} / \mathrm{kg}, \mathrm{MB}$ could cause high blood pressure, mental disorder, and abdominal pain (Albadarin et al., 2016).

Adsorption, ion exchange, and precipitation are some of the approaches that always have been improved to extract dyes, including MB, from wastewaters (Karaer \& Kaya, 2016). Adsorption is the most preferred technique to remove organic contaminants from an aqueous solution as it has produced results with high removal capacity (Alene et al., 2020). The effectiveness of the adsorption process is attributed to several factors related to the adsorbent used, for instance, large specific surface area, porous structure, enhanced functional groups and mineral components (Tan et al., 2015).

Adsorption of MB using adsorbents derived from agricultural waste-based biochar has received considerable attention in previous studies due to its low raw material cost and good adsorption capacity (Niran et al., 2018; Kuang et al., 2020). Its utilization as an adsorbent also helps to solve the problems of agricultural waste management. Several researches have been carried out on the use of chemically modified biochar as an adsorbent for the removal of MB. For example, sulfuric acid-treated coconut leaves biochar (Jawad et al. 2016), and phosphoric acid-treated PKS biochar (Niran et al., 2018) has been studied for MB adsorption from aqueous solution. Most previous studies focused on MB removal by acid/base treated biochar and rarely by minerals.

At the same time, previous studies indicated that $\mathrm{Mg}$ treatment could effectively improve the biochar properties and adsorption capacities. $\mathrm{Mg}$ salts and their oxides have several advantages for biochar's chemical treatment due to its low treatment cost, easy availability, and environmental soundness (Zhao et al., 2018). Mg salt which has a good dehydration ability could react with the carbohydrate polymers in biomass to maximize the release of volatile matter during pyrolysis. The process results in Mg-biochar composite with excellent porosity, which in turn, improves the adsorption properties (Shen et al., 2018). Mg-biochar composite has been studied for the removal of phosphate (Jung \& Ahn, 2015; Zhang et al., 2012), nitrate (Zhang et al., 2012), lead (Jellali et al., 2016), and levofloxacin (Zhao et al., 2018) from aqueous solution. However, there is currently no published information available on the applicability of Mg-PKS biochar composite to remove $\mathrm{MB}$ from an aqueous solution, especially concerning the removal efficiency and adsorption capacity. Considering the applicability of $\mathrm{Mg}$ biochars in treating several common pollutants in water, it is crucial to evaluate the potential application of $\mathrm{Mg}-\mathrm{PKS}$ biochar composites for removing common dyes, such as MB, from wastewater.

This paper reports the properties and application of Mg-PKS biochar composite derived from palm kernel shell (PKS) biochar for MB removal. In this work, Mg-PKS biochar 
composite was developed via steam activation of PKS biochar, which was followed by $\mathrm{Mg}$ treatment and carbonization. The efficiency of Mg-PKS biochar composite for the removal of MB from aqueous solution was investigated. The effect of process factors such as $\mathrm{pH}$, contact time and dosage via RSM were also determined.

\section{MATERIALS AND METHOD}

\section{Preparation of Mg-PKS Biochar Composite}

The PKS biochar used as a precursor for Mg-PKS biochar composite was prepared through fast carbonization via rotary kiln $\left(800^{\circ} \mathrm{C}, 10 \mathrm{~min}\right)$, followed by steam activation for $8 \mathrm{~h}$. The biochar was washed with distilled water to eliminate impurities and dried before mineral treatment. PKS biochar $(0.5 \mathrm{~mm}, 20 \mathrm{~g})$ were soaked in $500 \mathrm{~mL} \mathrm{MgSO}_{4} \cdot 7 \mathrm{H}_{2} \mathrm{O}\left(30^{\circ} \mathrm{C}, 60 \mathrm{~h}\right)$ (Zhao et al., 2018), vacuum filtered, and oven-dried $\left(90^{\circ} \mathrm{C}\right.$ for $12 \mathrm{~h}$ ). The $\mathrm{Mg}-\mathrm{PKS}$ biochar composite was then carbonized $\left(500^{\circ} \mathrm{C}, 30 \mathrm{~min}\right.$ ) (Zhao et al., 2018). The resulting Mg-PKS biochar composite was cooled to room temperature, rinsed with distilled water to remove debris, and dried prior to use.

\section{Adsorbent Characterization}

The proximate analyses of biochar samples were conducted based on ASTM D3173, ASTM D3174, and ASTM D3175. The carbon, hydrogen, nitrogen, sulfur, and oxygen content of the adsorbent were determined using CHNS Elemental Analyzer (Thermofisher Scientific Flashmart, United States). The Brunauer-Emmett-Teller (BET) analysis of surface area and pore volume of adsorbents were determined using Surface Area Analyzer (Quantachrome ${ }^{\circledR}$ ASiQwinTM, United States) with nitrogen $\left(\mathrm{N}_{2}\right)$ adsorption technique (Sartape et al., 2012). The functional groups of adsorbents were determined via Fourier Transform Infrared Spectroscopy (FTIR) (Thermo Nicolet Is10, United States) analysis.

\section{Stock Solution Preparation}

MB stock solution (Bendosen, Malaysia) was prepared by dissolving $1 \mathrm{~g}$ of MB in 1000 $\mathrm{ml}$ distilled water to obtain $1000 \mathrm{ppm}$ concentration (Fatiha \& Belkacem, 2015). UV/Vis spectrophotometer (JASCO V-730, Japan) at a wavelength of $665 \mathrm{~nm}$, was used to evaluate the concentration of MB. Calibration was conducted using various standard concentrations of MB solution (1, 2, 3, 4, 5, 6, and 7 ppm) (Hasbullah et al., 2014). The amount of MB absorbed at equilibrium, $\mathrm{q}_{\mathrm{e}}(\mathrm{mg} / \mathrm{g})$, was calculated using Equation 1 (Gnanasundaram et al., 2017).

$$
q_{e}=\left(\frac{\left(C_{0}-C_{e}\right) V}{W}\right)
$$


Whereas the adsorption efficiency (\%) of MB was calculated by using Equation 2 (Gnanasundaram et al., 2017).

$$
\text { Percentage removal }(\%)=\left(\frac{\left(C_{0}-C_{e}\right)}{C_{0}} \times 100\right) \quad \text { Equation } 2
$$

Where,

$\mathrm{C}_{0}=$ initial concentration of $\mathrm{MB}(\mathrm{mg} / \mathrm{l})$

$\mathrm{C}_{\mathrm{e}}=$ equilibrium concentration in liquid phase (mg/l)

$\mathrm{V}=$ volume of solution

$\mathrm{W}=$ mass of adsorbent

\section{Adsorption Study via Response Surface Methodology (RSM) approach}

Response surface methodology (RSM) with central composite design (CCD) was employed to optimize the MB removal parameters by Mg-PKS biochar composite. RSM was chosen as the statistical technique to verify the relationships between the independent parameters and their effect on the adsorption (Mousavi et al., 2017). CCD was applied to study the effects of $\mathrm{pH}$ (4-10), contact time (30-90 min) and adsorbent dosage (0.1-0.5 g) on the removal efficiency of MB by Mg-PKS biochar composite (Table 1). Each factor was ranged in terms of +1 and -1 , signifying high and low levels, respectively.

Table 1

Experimental factors design using CCD

\begin{tabular}{lccc}
\hline Parameters & Units & Low & High \\
\hline $\mathrm{pH}$ & $\mathrm{pH}$ & 4 & 10 \\
Contact time & $\mathrm{min}$ & 30 & 90 \\
Adsorbent dosage & $\mathrm{g}$ & 0.1 & 0.5 \\
\hline
\end{tabular}

\section{RESULTS AND DISCUSSION}

\section{Preparation of Mg-PKS Biochar Composite}

The modification of PKS biochar was carried out to improve the adsorption capability of the biochar as an adsorbent. In this study, PKS biochar was chemically modified with magnesium sulfate. Scheme 1 displayed the proposed mechanism for the impregnation of $\mathrm{Mg}$ on biochar.

The compound was formed during the modification process of biochars, where the biochars were soaked in magnesium sulphate. The $\mathrm{Mg}^{2+}$ from $\mathrm{MgSO}_{4}$ would bind or attract the negatively charged biochar, as shown in the equation as follows. 


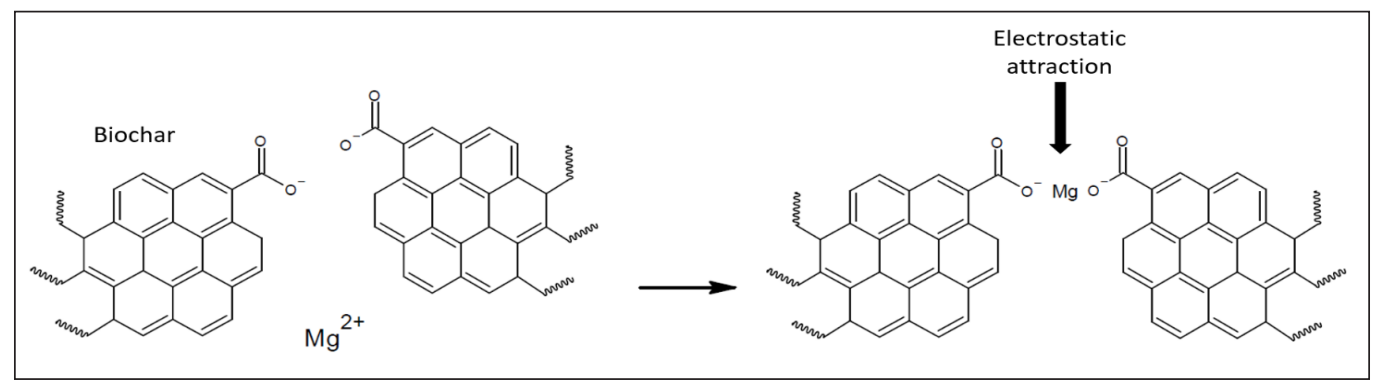

Scheme 1. Proposed mechanism for modification of Mg-PKS biochar composite

$$
\mathrm{MgSO}_{4}(s)+\mathrm{H}_{2} \mathrm{O}(l) \rightarrow \mathrm{Mg}^{2+}(a q)+\mathrm{SO}_{4}^{2-}(a q)
$$

$\mathrm{Mg}$ is a positively charged compound as well as $\mathrm{MB}$, thus, the repulsion between $\mathrm{Mg}$ and MB might happen. However, based on the SEM image of Mg-PKS biochar composite (Figure 1b), it can be observed that the Mg-treatment did not cover the whole biochar surface, thus leaving the negatively charged surface as it is, indicating that electrostatic interaction might occur between Mg-PKS biochar composite and MB. Cation exchange might also involve the adsorption of MB onto PKS biochar (Fan et al., 2016; Zhu et al., 2015). MB is widely used as a standard reagent for cation exchange determination in soil (Zhu et al., 2015). Scheme 2 is the proposed mechanism of MB adsorption onto the surface of Mg PKS biochar.

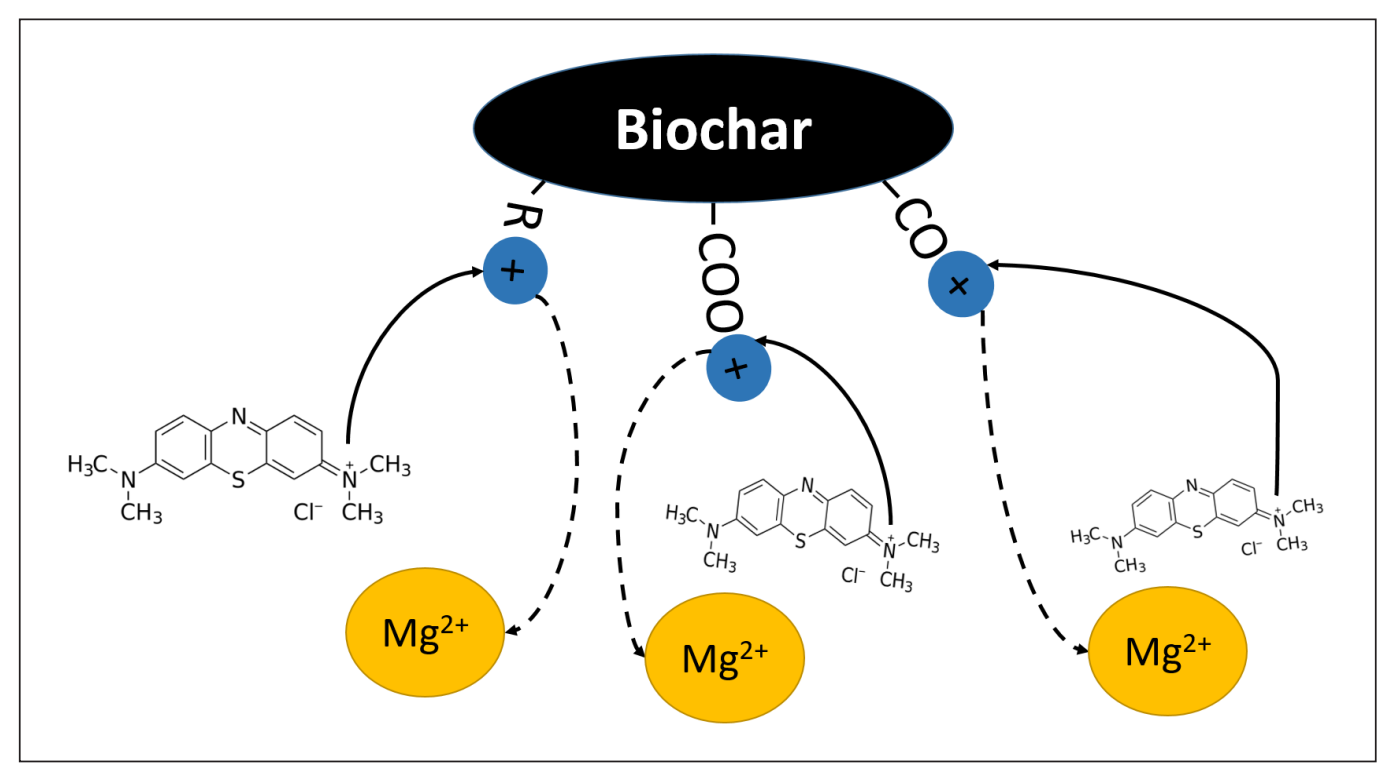

Scheme 2. Proposed mechanism of the adsorption of MB onto the surface of Mg PKS biochar 
The occurrence of cation exchange during the adsorption of MB might occur when $\mathrm{Mg}$ compounds on the biochar surface are released and replaced with MB. The possibility of intraparticle diffusion and pore diffusion to occur is also higher during the adsorption of MB onto all chemically modified biochar (Fan et al., 2016; Mahmoudi et al., 2015). Surface complexation comprising a few functional groups such as $-\mathrm{CH},-\mathrm{OH},-\mathrm{CO}$, and $-\mathrm{COOH}$ are inclined to be involved in MB binding onto the surface of biochar as well (Fan et al., 2016). The aromatic structures of both biochar and MB could instigate $\pi-\pi$ (pi) stacking interactions, causing $\mathrm{MB}$ to be readily adsorbed by biochar, facilitating the adsorption process (Wu et al., 2014).

\section{Adsorbent Characterization}

Ultimate and Proximate Analysis. Table 2 displays the element content of the Mg-PKS biochar composite for both ultimate and proximate analysis. The highest element content in the samples is carbon, followed by other elements like oxygen, hydrogen, nitrogen and sulfur. Carbon and oxygen can be regarded as significant elements in the samples, while hydrogen, nitrogen and sulfur are the minor elements since they are in low concentration (Liew et al., 2017).

Table 2

Ultimate and proximate analysis for steam activated biochar and $M g-P K S$ biochar composite

\begin{tabular}{lcclcc}
\hline \multicolumn{2}{c}{ Ultimate analysis } & \multicolumn{3}{c}{ Proximate analysis } \\
\hline Elements & $\begin{array}{c}\text { Steam activated } \\
\text { biochar (\%) }\end{array}$ & $\begin{array}{c}\text { Mg-PKS biochar } \\
\text { composite (\%) }\end{array}$ & Elements & $\begin{array}{c}\text { Steam activated } \\
\text { biochar (\%) }\end{array}$ & $\begin{array}{c}\text { Mg-PKS biochar } \\
\text { composite }(\%)\end{array}$ \\
\hline Carbon & 70.37 & 62.81 & $\begin{array}{l}\text { Moisture } \\
\text { content }\end{array}$ & 10.81 & 19.28 \\
Hydrogen & 2.02 & 1.70 & Ash content & 26.62 & 28.48 \\
Nitrogen & 0.25 & 0.34 & Volatile matter & 45.90 & 14.26 \\
Oxygen & 26.78 & 32.72 & Fixed carbon & 11.84 & 37.97 \\
Sulfur & 0.57 & 2.43 & & & \\
\hline
\end{tabular}

High carbonization temperature enhances the carbon content of biochar, related to the aromatic part of the biochar (Wahi et al., 2015). Carbon content is an essential aspect of identifying valuable and excellent biochar (Mahmood et al., 2015). From Table 2, it can be observed that Mg-PKS biochar composite has a high fraction of carbon content of $62.81 \%$. This biochar can be regarded as a promising biochar owing to the fact that its carbon content is higher than 60\% (Mahmood et al., 2015). There is no significant change in nitrogen content since nitrogen functional groups cannot generate vaporized molecules, but they can produce complex substances (Fang et al., 2014). In terms of sulfur content, there is a high 
possibility that sulfur was not detectable in raw PKS because the concentration discovered was below the lowest detection limit of the CHN analyzer (Liew et al., 2017). Mg-PKS biochar composite exhibits a negligibly low concentration of sulfur of $2.43 \%$. The sulfur content might be derived from the sulfate of $\mathrm{MgSO}_{4} \cdot 7 \mathrm{H}_{2} \mathrm{O}$ during the loading process.

Mg-PKS biochar composite shows high moisture content (19.28\%), which might be due to biochar being soaked in $\mathrm{MgSO}_{4} \cdot 7 \mathrm{H}_{2} \mathrm{O}$ solution for $60 \mathrm{~h}$. The reason might be caused by the washing process during the modification of the PKS biochar. Biomass with a moisture content of more than or equal to $40 \%$ is not deemed suitable for carbonization since the process will require more energy and time, which are not economically feasible (Tripathi et al., 2016). Ash content is incombustible minerals such as calcium, magnesium, phosphorus, sodium, potassium, and iron found in the biomass (Pinto et al., 2019; Patel \& Gami, 2012). Mg-PKS biochar composite has an ash content of $28.48 \%$, which is likely due to the addition of Mg minerals in the biochar (Zhao et al., 2018).

Volatile matter contains flammable gases, namely methane, hydrogen, oxygen and carbon monoxide, and non-flammable gases (Sarkar, 2015). The volatile matter for the Mg-PKS biochar composite is $14.26 \%$. High-volatile biochar combusts more readily than biochar with low volatile matter due to a high amount of combustible gases (Sarkar, 2015). The high temperature used during the carbonization process was responsible for the volatile matter to discharge from weaker bonds hence being released to the atmosphere (Antunes et al., 2017). Biochar with low residual volatile matter is a valuable characteristic of the biochar to act as an adsorbent. The chemical compounds that might be released by the remaining volatile matter in the biochar may react with reactants or products that are parts of any suitable chemical reaction and then produce side products or solely contaminate the products straight away (Lam et al., 2018). High release of volatile matter leads to the production of biochar with additional new pores, hence improving the surface area of the biochar (Liu et al., 2015; Wahi et al., 2015).

Fixed carbon is the residue left in the biochar after devolatilization occurs, and subtracts moisture and ash content (Sarkar, 2015). It is fundamentally carbon comprises of oxygen, hydrogen, nitrogen and sulfur, which are in small quantity (Sarkar, 2015). The fixed carbon in the biochar has the possibility to develop the structure of carbons into pores, which further denotes the potential improvement of the adsorption sites of the biochar (Liew et al., 2017).

SEM Analysis. SEM analysis was piloted to observe the external morphology and pores formation of steam activated PKS biochar and Mg-PKS biochar composite, as revealed in Figure 1a and b, respectively. The presence of pores can be seen clearly in the sample consisting of both small and large pores. The large pores could efficiently enhance many liquid-solid adsorption processes (Rout et al., 2016). Highly porous biochar has the benefit 

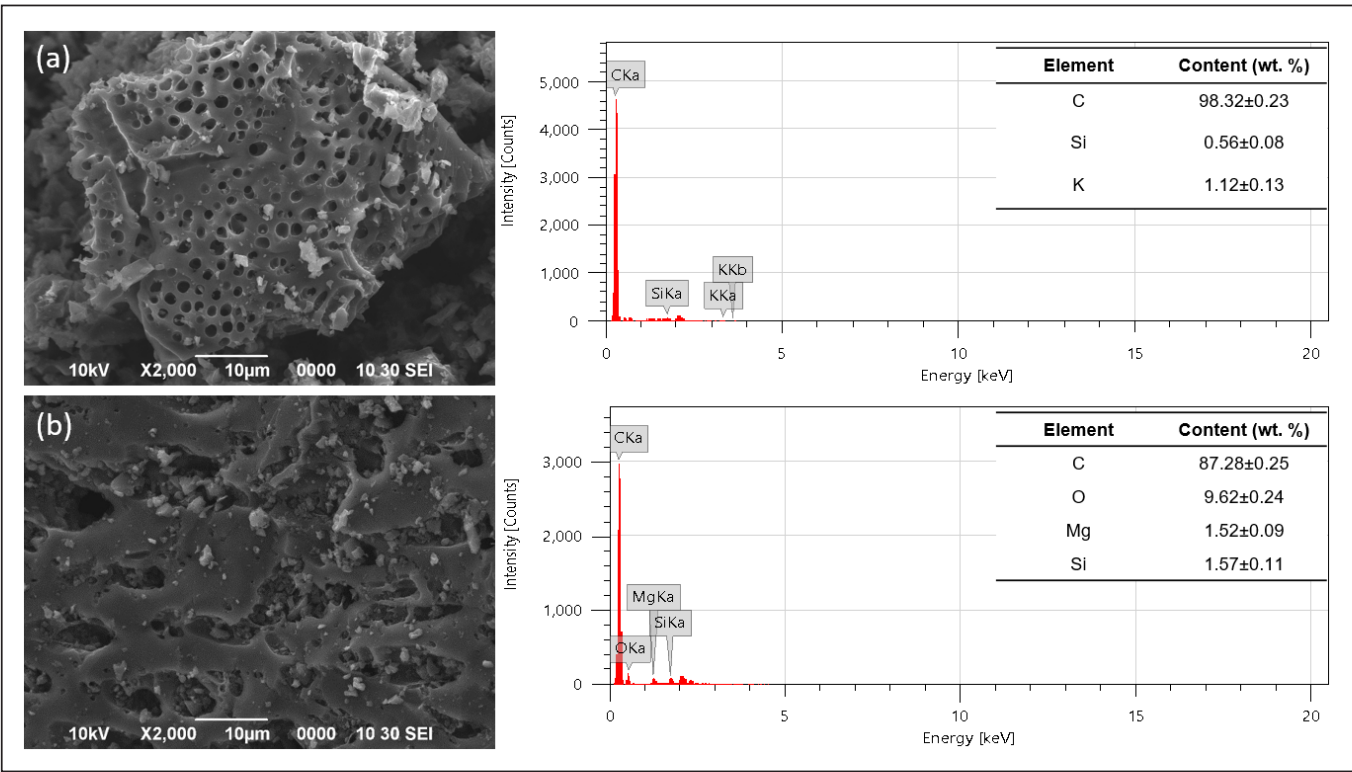

Figure 1. SEM and EDX spectra images of (a) steam activated PKS biochar 2000x, (b) Mg-PKS biochar composite $2000 \times$

of more adsorption of organic pollutants (Rout et al., 2016). Mg-PKS biochar composite displayed irregular-shaped pore structures, including a few notable particles that might be the chemicals. Mg component has been adequately coated on the biochar since the presence of $\mathrm{Mg}$ particles can be spotted on the surface of the biochar. The negatively charged surface of biochar attracted the positively charged $\mathrm{Mg}$, thus facilitating the coating process onto the biochar's surface (Rajapaksha et al., 2016). Figure 1 also provides energy dispersive spectroscopic (EDX) results that verify the presence of elements such as carbon $(\mathrm{C})$, silicon $(\mathrm{Si})$, magnesium $(\mathrm{Mg})$, oxygen $(\mathrm{O})$ and potassium $(\mathrm{K})$ in both biochars. Figure 1a indicated that steam activated PKS biochar comprised of $\mathrm{C}$, Si and $\mathrm{K}$ with a weight percentage of $98.32 \pm 0.23 \%, 0.56 \pm 0.08 \%$ and $1.12 \pm 0.13 \%$, respectively. Whereas in Figure $1 \mathrm{~b}$, the EDX spectra proved the presence of $\mathrm{Mg}$ in the Mg-PKS biochar composite with a weight percentage of $1.52 \pm 0.09 \%$. The presence of $\mathrm{C}, \mathrm{O}$ and $\mathrm{Si}$ in biochar was also validated with weight percentages of $87.28 \pm 0.25 \%, 9.62 \pm 0.24 \%$ and $1.57 \pm 0.11 \%$, respectively. Steam activated PKS biochar has average pore diameters of $1.80 \pm 0.32 \mu \mathrm{m}$ while Mg-PKS biochar composite with average pore diameters of $7.2195 \pm 3.5404 \mu \mathrm{m}$.

BET Analysis. The surface area and total pore volume of the Mg-PKS biochar composite were computed using the BET instrument. Surface area and pore volume are a few of the essential characteristics for carbon adsorbent, namely charcoal, activated carbon and biochar, to identify its adsorption capacity (He et al., 2018). The bigger the surface area, the better its adsorptive capacity (Liao et al., 2013). In the current study, the sample was 
ground to the size of $0.50 \mathrm{~mm}$. The results discovered that the surface area and total pore volume of steam activated PKS biochar are $592 \mathrm{~m}^{2} \mathrm{~g}^{-1}$ and $0.353 \mathrm{~cm}^{3} \mathrm{~g}^{-1}$. Table 3 displayed the comparison of surface area and total pore volume for raw PKS, PKS biochar and MgPKS biochar composite.

Table 3

Surface area and total pore volume for raw PKS, PKS biochar and Mg-PKS biochar composite

\begin{tabular}{lccc}
\hline Sample & Raw PKS & PKS biochar & Mg-PKS biochar composite \\
\hline Surface area $\left(\mathrm{m}^{2} \mathrm{~g}^{-1}\right)$ & 0.848 & 592 & 674 \\
Total pore volume $\left(\mathrm{cm}^{3} / \mathrm{g}\right)$ & 0.003 & 0.353 & 0.424 \\
\hline
\end{tabular}

Chemical activation and high carbonization temperature affect the size of the surface area of biochar, which leads to the development of additional pores on the biochar (Antunes et al., 2017). Volatile matters discharged during carbonization assist the pore formation in the biochar structure (Antunes et al., 2017). In addition, steam explosion can also affect the size of the surface area of biochar, which can be observed in previous study where biochar derived from wheat, rice, and cotton straws displayed a large specific surface area (>180 $\mathrm{m}^{2} / \mathrm{g}$ ) (Xue-jiao et al., 2019). The Mg-PKS biochar composite was able to show the highest surface area, which is $674 \mathrm{~m}^{2} \mathrm{~g}^{-1}$. The plausible reason for the high surface area is the reaction between $\mathrm{MgCl}_{2}$, which has a good dehydration ability, and the carbohydrate polymers in biomass. The reaction increases the release of volatile matter and enables the creation of more pores during pyrolysis at high temperature (Shen et al., 2018). Shen et al. (2018) showed a similar result where MgO-treated corncob biochar $\left(26.56 \mathrm{~m}^{2} \mathrm{~g}^{-1}\right)$ has a greater surface area than the surface area of corncob biochar which is $0.07 \mathrm{~m}^{2} \mathrm{~g}^{-1}$.

However, a few studies displayed different results where the surface area of $\mathrm{Mg}$ PKS biochar composite is smaller than the PKS biochar due to the accumulation of $\mathrm{Mg}$ elements on the surface of biochar (Fang et al., 2014; Riddle et al., 2019). Mg-PKS biochar composite made from PKS displayed a relatively large surface area compared to other feedstocks such as corncob and wood chips, where at least numerous of them are below $<500 \mathrm{~m}^{2} \mathrm{~g}^{-1}$ (Shen et al., 2018; Zhao et al., 2018). The outcome shows that the chemical modification of PKS biochar has increased its surface area and adsorption capacity. Table 4 presented the comparison of surface properties between Mg-PKS biochar composite and other chemically modified biochars. Mg-PKS biochar composite has the highest surface area $\left(674 \mathrm{~m}^{2} \mathrm{~g}^{-1}\right)$ compared to other Mg biochars and other chemically modified biochars.

FTIR Analysis. The information on the existence of various surface functional groups of the samples is obtained by FTIR spectroscopy. The FTIR spectra of the Mg-PKS biochar composite are presented in Figure 2. The main characteristics that indicate cellulose, hemicellulose, and lignin in the PKS biochar are when the functional groups such as 
Table 4

Comparison of Mg-PKS biochar composite surface properties with other $\mathrm{Mg}$ treated biochars

\begin{tabular}{lcccl}
\hline \multirow{2}{*}{ Biochar } & \multicolumn{4}{c}{ Characteristics } \\
\cline { 2 - 5 } & $\begin{array}{c}\text { Surface area } \\
\left(\mathrm{m}^{2} \mathrm{~g}^{-1}\right)\end{array}$ & $\begin{array}{c}\text { Pore volume } \\
\left(\mathrm{cm}^{3} \mathrm{~g}^{-1}\right)\end{array}$ & $\begin{array}{c}\text { Total pore } \\
\text { diameters }(\mu \mathrm{m})\end{array}$ & Reference \\
\hline Mg-PKS biochar composite & 674 & 0.424 & $7.22 \pm 3.54$ & Present study \\
MgO-treated corncob biochar & 26.56 & - & - & Shen at al. (2018) \\
Mg modified biochar & 490.294 & - & - & Fang et al. (2014) \\
MgO-impregnated wood chips & 225 & - & - & Zhao et al. (2018) \\
biochar & 12.65 & 0.0133 & 0.0042 & Carvalho et al. (2019) \\
Mg-treated carrot biochar & 66.1 & - & - & Riddle et al., (2019) \\
Mg-impregnated biochar & & &
\end{tabular}

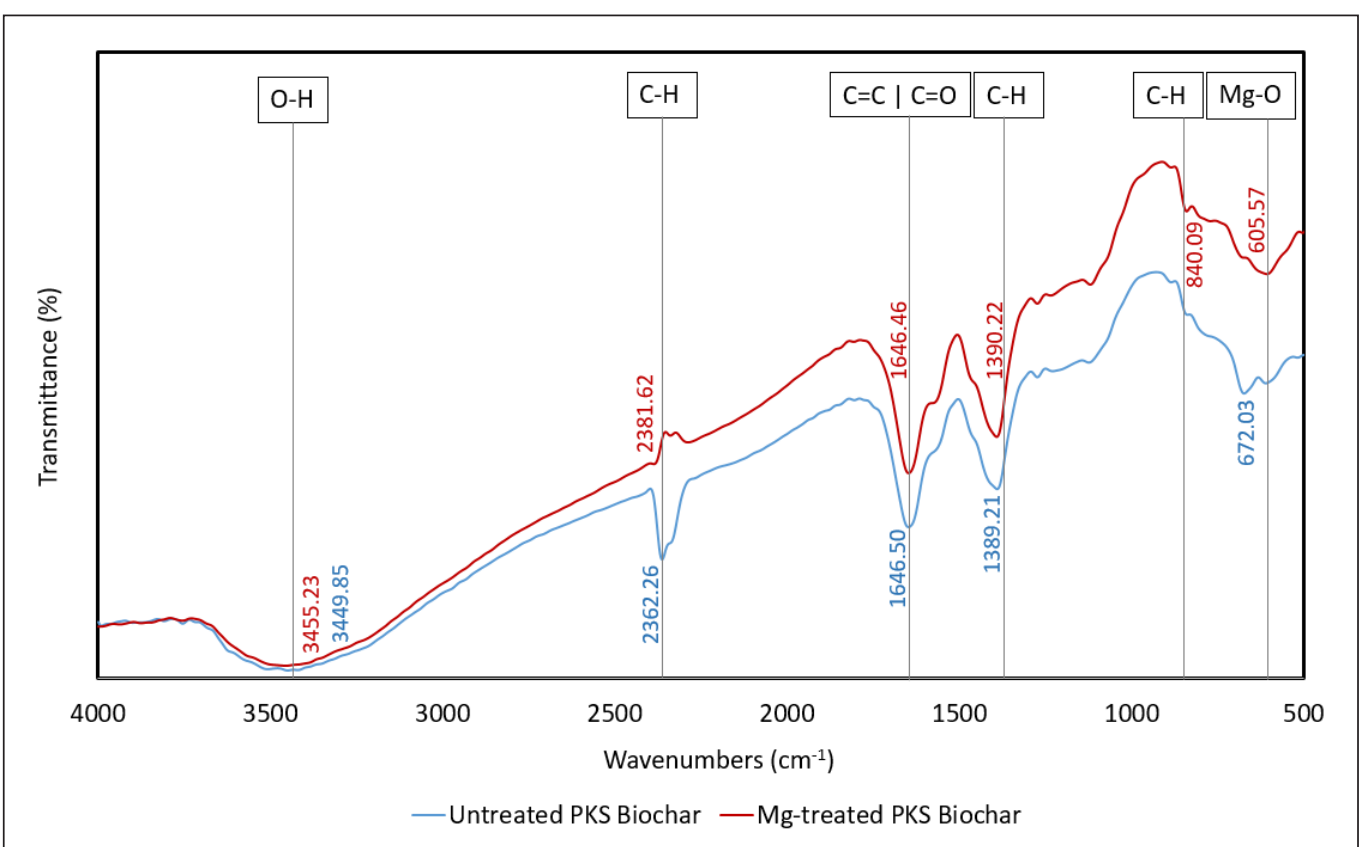

Figure 2. FTIR spectra for steam activated PKS biochar and Mg-PKS biochar composite

$\mathrm{C}-\mathrm{O}, \mathrm{C}=\mathrm{O}, \mathrm{C}-\mathrm{H}$ and $\mathrm{O}-\mathrm{H}$ present in the spectra (Johari et al., 2016). The bands that are slightly shifted to a new one in biochar demonstrate that chemical exchanges transpired on the modified biochar surface (Komnitsas \& Zaharaki, 2016). The presence of strong and broad bands between 3200 and $3500 \mathrm{~cm}^{-1}$ could be deduced to the $\mathrm{O}-\mathrm{H}$ stretching vibrations indicative of hydroxyl group and water adsorption by the samples (García et al., 2018). This peak range is also ascribed to the presence of crystalline cellulose (Liu \& Han, 2015). From the Figure 2, the peaks at $3455.23 \mathrm{~cm}^{-1}$ and $3449.85 \mathrm{~cm}^{-1}$ ascribe to $\mathrm{O}-\mathrm{H}$ stretching vibrations demonstrating the presence of chemical compounds like alcohol, phenol, or carboxylic acid (Liew et al., 2017). 
A series of peaks at $800-400 \mathrm{~cm}^{-1}$ in the case of Mg-PKS biochar composite can be credited to $\mathrm{Mg}-\mathrm{O}$ and $\mathrm{O}-\mathrm{Mg}-\mathrm{O}$, which suggests the presence of $\mathrm{Mg}$ oxyhydroxides (Zhao et al., 2018). The peaks of the Mg-PKS biochar composite imply that magnesium particles do not influence the structure of functional groups in Mg-PKS biochar composite (Fang et al., 2014). Additional OH groups were produced on Mg-PKS biochar composite, which may be responsible for the adsorption ability of biochar (Zhao et al., 2018). The bands at around $600 \mathrm{~cm}^{-1}$ in all samples can also be assigned to $\mathrm{C}-\mathrm{H}$ bending vibrations in aromatic compounds (Komnitsas \& Zaharaki, 2016).

The peaks at 1646.50 and $1646.46 \mathrm{~cm}^{-1}$ can be consigned to carbon species in the form of $\mathrm{C}=\mathrm{C}$ stretching vibration, suggesting the presence of aromatic and alkene compounds in the samples (Liew et al., 2017; Rugayah et al., 2014). Similarly, according to Jindo et al. (2014), the peaks between $1650 \mathrm{~cm}^{-1}$ and $1620 \mathrm{~cm}^{-1}$ may also denote the presence of $\mathrm{C}=\mathrm{C}$ stretching vibration indicative of the aromatics group, which appears for all samples. On the contrary, Johari et al. (2016) proposed that the peaks around $\sim 1600 \mathrm{~cm}^{-1}$ can be attributed to $\mathrm{C}-\mathrm{O}$ or $\mathrm{C}=\mathrm{O}$ stretching vibration corresponding to functional groups like alcohols, esters, ether, and carboxylic acid. Correspondingly, García et al. (2018) also agreed that the band around $1625 \mathrm{~cm}^{-1}$ signifies the presence of $\mathrm{C}=\mathrm{O}$ deformation of aldehydes, ketones, and carboxyl groups. Notably, the $\mathrm{C}-\mathrm{H}\left(-\mathrm{CH}_{2}\right.$ and $\left.-\mathrm{CH}_{3}\right)$ bending vibrations at the peaks ranged from 1407.81 to $1388.26 \mathrm{~cm}^{-1}$ in all samples, possibly indicate the presence of alkanes components. The peaks around $\sim 2350 \mathrm{~cm}^{-1}$ represent strong $\mathrm{O}=\mathrm{C}=\mathrm{O}$ stretching vibrations in all biochar samples, showing carbon dioxide (Komnitsas \& Zaharaki, 2016). Table 5 summarized the peaks obtained in this study.

Table 5

Summary of the peaks obtained from FTIR spectra

\begin{tabular}{llcc}
\hline \multirow{2}{*}{$\begin{array}{c}\text { Wavenumber } \\
\left(\mathrm{cm}^{-1}\right)\end{array}$} & \multicolumn{1}{c}{ Assignments } & \multicolumn{2}{c}{ Wavenumber of samples $\left(\mathrm{cm}^{-1}\right)$} \\
\cline { 2 - 4 } & \multicolumn{1}{c}{$\begin{array}{c}\text { Steam activated } \\
\text { PKS biochar }\end{array}$} & $\begin{array}{c}\text { Mg-PKS biochar } \\
\text { composite }\end{array}$ \\
\hline $3500-3200$ & $\begin{array}{l}\text { O-H stretching indicative of alcohol, phenol or } \\
\text { carboxylic acid }\end{array}$ & 3449.85 & 3455.23 \\
$\sim 2350$ & $\mathrm{CO}_{2}$ stretching & 2362.26 & 2381.62 \\
$1700-1600$ & $\mathrm{C}=\mathrm{O}$ or C=C stretching in aromatic ring or & 1646.50 & 1646.46 \\
& alkenes & & 1389.21 \\
$1500-1300$ & $\mathrm{C}-\mathrm{H}\left(\mathrm{CH}_{2}\right.$ and $\left.\mathrm{CH}_{3}\right)$ bending in alkanes & 672.03 & 605.57 \\
$900-600$ & $\mathrm{C}-\mathrm{H}$ bending vibrations in aromatic compounds & - & 605.57 \\
$800-400$ & $\mathrm{Mg}-\mathrm{O}$ and $\mathrm{O}-\mathrm{Mg}-\mathrm{O}$ & & \\
\hline
\end{tabular}

\section{Adsorption Study via the RSM approach}

MB removal via adsorption by $\mathrm{Mg}$-PKS biochar composite to determine the independent parameters, namely $\mathrm{pH}$ (factor A), contact time (factor B), and adsorbent dosage (factor 
C), with their effect on removal of MB. Mg-PKS biochar composite is chosen for the optimization study because it showed the highest MB removal percentage compared to other biochar. Optimization of MB adsorption study was finalized using central composite design (CCD), a sub-program of RSM, through Design-Expert (version 12.0) software. The response can be associated with the operating parameters by linear or quadratic models (Ozturk \& Sahan, 2015). Seventeen experimental runs were carried out to develop the correlation between the functional variables of Mg-PKS biochar composite to the removal of MB from an aqueous solution. The parameters used in this study are $\mathrm{pH}(4-10)$, contact time (30-90 $\mathrm{min})$ and adsorbent dosage $(0.1-0.5 \mathrm{~g})$, as well as their response (percentage MB removal efficiency).

Based on Table 6, MB removal efficiency by Mg-PKS biochar composite ranged between $59.44 \%$ and $98.50 \%$. Run 6 has the highest MB removal efficiency, $98.50 \%$, operated at $\mathrm{pH} 10$, contact time of $30 \mathrm{~min}$ and adsorbent dosage of $0.5 \mathrm{~g}$. Simultaneously, Run 1 displayed the lowest removal efficiency of MB of $59.44 \%$ with an adsorbent dosage of $0.1 \mathrm{~g}$, a contact time of $30 \mathrm{~min}$ and $\mathrm{pH}$. MB reached equilibrium after $30 \mathrm{~min}$ based on the experimental data for the lowest and highest removal efficiency of MB. This result is supported by a few types of research that also recommended the sufficient time taken for removal of MB to attain equilibrium is $30 \mathrm{~min}$ (Bendaho et al., 2015; Ocholi et al., 2016;

Table 6

Experimental factors and response for $M B$ removal by $M g$-PKS biochar composite

\begin{tabular}{cccccc}
\hline \multicolumn{3}{c}{ Parameters } & & \multicolumn{2}{c}{ Mg-PKS biochar composite } \\
\hline Run & $\mathrm{pH}$ & Time (min) & Dosage $(\mathrm{g})$ & $\begin{array}{c}\text { Actual MB removal } \\
\text { efficiency }(\%)\end{array}$ & $\begin{array}{c}\text { Predicted MB removal } \\
\text { efficiency }(\%)\end{array}$ \\
\hline 1 & 4 & 30 & 0.1 & 59.44 & 58.96 \\
3 & 10 & 30 & 0.1 & 91.03 & 92.00 \\
4 & 4 & 90 & 0.1 & 86.10 & 83.95 \\
5 & 4 & 90 & 0.1 & 85.31 & 85.27 \\
6 & 10 & 30 & 0.5 & 79.83 & 79.70 \\
7 & 4 & 90 & 0.5 & 98.50 & 100.48 \\
8 & 10 & 90 & 0.5 & 88.57 & 87.44 \\
9 & 4 & 60 & 0.3 & 76.17 & 76.49 \\
10 & 10 & 60 & 0.3 & 75.72 & 79.61 \\
11 & 7 & 30 & 0.3 & 93.88 & 90.65 \\
12 & 7 & 90 & 0.3 & 75.06 & 72.72 \\
13 & 7 & 60 & 0.1 & 70.23 & 73.23 \\
14 & 7 & 60 & 0.5 & 87.54 & 89.24 \\
15 & 7 & 60 & 0.3 & 96.27 & 95.23 \\
16 & 7 & 60 & 0.3 & 87.16 & 83.65 \\
17 & 7 & 60 & 0.3 & 88.20 & 83.65 \\
\hline
\end{tabular}


Tang et al., 2017). The highest (Run 6) and the second highest (Run 14) percentage MB removal have the adsorbent dosage of $0.5 \mathrm{~g}$, whereas the lowest (Run 1) and the second lowest (Run 12) percentage MB removal with an adsorbent dosage of $0.1 \mathrm{~g}$ and $0.3 \mathrm{~g}$, respectively. The removal of MB amplified as the adsorbent dosage increased. It might be due to the improved availability of the adsorption sites and surfaces of the adsorbents (Pathania et al., 2017).

Run 6 has a pH of 10, indicative of alkaline solution, while Run 1 has a $\mathrm{pH}$ of 4 , signifying that the solution system is acidic. Alteration of $\mathrm{pH}$ value can enhance the adsorption process (Guarín et al., 2018). When $\mathrm{pH}$ condition is low (acidic), there is an electrostatic repulsion between hydrogen ions, magnesium ions and the positively charged $\mathrm{MB}$ ions on the biochar surface, thus restricting the adsorption process of MB on the negatively charged adsorbent (Marrakchi et al., 2017; Pandimurugan \& Thambidurai, 2016; Pang et al., 2017). At high pH conditions (alkali), deprotonation took place on the biochar surface, causing the surface to become negatively charged, assisting the adsorption of MB (Guarín et al., 2018). Hence, it is recommended to conduct adsorption of MB at a $\mathrm{pH}$ value of 10 .

Design-Expert software provided a few statistical tables such as linear, two-factor interaction (2F1), quadratic and cubic polynomials to classify the suitable model to describe the relationships between the parameters and the responses for the adsorption study (Stat Ease, 2019). The present study found that the quadratic model fits the data as the software suggested it since the model has the highest $\mathrm{R}^{2}$, adjusted $\mathrm{R}^{2}$ and predicted $\mathrm{R}^{2}$, which are $0.9186,0.8139$ and 0.6531 , respectively, as compared to other models. The multiple correlation coefficient, $\mathrm{R}^{2}$, nearer to 1 , indicates a better correlation between experimental and predicted values (Thakkar \& Saraf, 2014). The equations of the quadratic model are as follows (Equation 3):

MB removal efficiency $(\%)=83.65+5.52 \mathrm{~A}+0.2520 \mathrm{~B}+2.99 \mathrm{C}-7.93 \mathrm{AB}-3.07 \mathrm{AC}$ $-4.32 \mathrm{BC}+1.4 .8 \mathrm{~A}^{2}-10.68 \mathrm{~B}^{2}+8.58 \mathrm{C}^{2}$ Equation 3

$\mathrm{A}, \mathrm{B}$ and $\mathrm{C}$ represent $\mathrm{pH}$ of a solution, contact time and adsorbent dosage, respectively. The coefficient with one factor illustrates the effects of the variable itself, whereas the coefficient with two factors demonstrates the effect of the interaction between two factors (Wahi et al., 2014). Furthermore, the coefficient with the power of two represents the effect of quadratic factors. The negative signs denote the antagonistic effect, and the positive signs display synergistic effects (Wahi et al., 2014).

Figure 3 revealed the predicted versus actual plot of $\mathrm{MB}$ removal efficiency for $\mathrm{Mg}-\mathrm{PKS}$ biochar composite. Based on the Figure 3, the scheme presented an excellent capability of the developed quadratic model, which fit all the experimental results due to the apparent 
small distances between the cluster of points and the diagonal line. Ideally, all the points are reasonably near the diagonal line, which can be observed from the Figure 3. When the actual removal efficiency is $59.44 \%$, the predicted value should be considered close to the real value, $58.96 \%$.

Design-Expert software can also be applied to evaluate the statistical analyses to visualize the effects of the selected parameters on the Mg-PKS biochar composite adsorption capacity. Analysis of variance (ANOVA) is utilized to assess the numerical significance of the quadratic

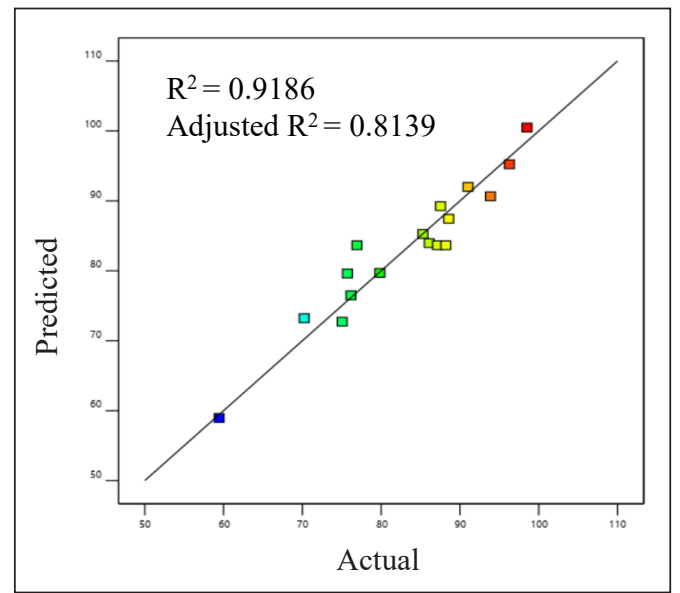

Figure 3. Predicted vs actual removal efficiency of $\mathrm{MB}$ using $\mathrm{Mg}-\mathrm{PKS}$ biochar composite model equation between $\mathrm{pH}$ value, contact time and adsorbent dosage, as displayed in Table 7. ANOVA is summarized by presenting the sum and mean of squares for each factor, degree of freedoms, F-values, and p-values. The significance of the quadratic model is analyzed by using F-test ANOVA. The model with the F-value of 8.78 showed that the model is significant. There is only a $0.46 \%$ possibility that this large F-value could ensue because of noise. When the F-value of the factor is getting larger, its effect on the response will also become greater (Kim, 2014). Prob > F or p-values less than 0.05 signify that

Table 7

ANOVA results of the regression model for the optimization of $M B$ adsorption by $M g-P K S$ biochar composite

\begin{tabular}{lcccccc}
\hline Source & $\begin{array}{c}\text { Sum of } \\
\text { Squares }\end{array}$ & $\begin{array}{c}\text { Degree of } \\
\text { Freedom }\end{array}$ & $\begin{array}{c}\text { Mean } \\
\text { Square }\end{array}$ & F-value & $\begin{array}{c}\text { p-value } \\
\text { Prob>F }\end{array}$ & \\
\hline Model & 1503.20 & 9 & 167.02 & 8.78 & 0.0046 & significant \\
A-pH & 305.04 & 1 & 305.04 & 16.03 & 0.0052 & \\
B-Time & 0.64 & 1 & 0.64 & 0.03 & 0.8602 & \\
C-Dosage & 89.52 & 1 & 89.52 & 4.70 & 0.0667 & \\
AB & 503.24 & 1 & 503.24 & 26.44 & 0.0013 & \\
AC & 75.22 & 1 & 75.22 & 3.95 & 0.0871 & \\
BC & 149.04 & 1 & 149.04 & 7.83 & 0.0266 & \\
A $^{2}$ & 5.85 & 1 & 5.85 & 0.31 & 0.5967 & \\
B $^{2}$ & 305.48 & 1 & 305.48 & 16.05 & 0.0051 & \\
C $^{2}$ & 197.33 & 1 & 197.33 & 10.37 & 0.0147 & \\
Residual & 133.22 & 7 & 19.03 & & & \\
Lack of Fit & 55.64 & 5 & 11.13 & 0.29 & 0.8873 & not significant \\
Pure Error & 77.582 & 2 & 38.79 & & & \\
Correlation Total & 1636.42 & 16 & & & & \\
\hline
\end{tabular}


the model terms used are significant (Thakkar \& Saraf, 2014; Wahi et al., 2014). In this study, factors $\mathrm{A}, \mathrm{AB}, \mathrm{BC}, \mathrm{B}^{2}$ and $\mathrm{C}^{2}$ are regarded as significant model terms. The 'lack of fit F-value' of 0.29 denotes the lack of fit value is insignificant relative to the pure error. There is an $88.73 \%$ probability that this massive 'lack of fit F-value' could happen because of noise. Non-significant lack of fit is compulsory for the model to fit.

In the present work, the $\mathrm{pH}$ value of the solution attained the highest F-value (16.03) amongst contact time (0.03) and adsorbent dosage (4.70), with a p-value of 0.0052 (less than 0.05), indicating that $\mathrm{pH}$ factor has substantial influence in the removal of $\mathrm{MB}$ by Mg-PKS biochar composite. The interaction between the effects of $\mathrm{pH}$ and time (AB) obtained a high F-value of 26.44 and p-value of 0.0013 as well as the effects of time and dosage (BC) (F-value of 7.83; p-value of 0.0266), proving that the respective interactions give a significant result on the responses whereas AC (F-value of 3.95; p-value of 0.0871) has fewer notable effects. The quadratic function of the effect of contact time $\left(\mathrm{B}^{2}\right)$ and adsorbent dosage $\left(\mathrm{C}^{2}\right)$ with high $\mathrm{F}$-values of 16.05 and 10.37, respectively, have a better remarkable effect as compared to the effect of $\mathrm{pH}\left(\mathrm{A}^{2}\right)$ with a lower F-value of 0.31 .

Three-dimensional response surface graphs that are disclosed in Figure 4a-c describe the behaviour of the combined effects of various parameters on MB removal efficiency. Figure 4 shows, 3D response surface graph and contour plot, are showing the effect of (a) $\mathrm{pH}$ and time, (b) time and adsorbent dosage, and (c) $\mathrm{pH}$ and adsorbent dosage on $\mathrm{MB}$ removal efficiency by Mg-PKS biochar composite.

Figure $4 \mathrm{a}$ showed that shorter contact time is needed as the $\mathrm{pH}$ value increased to achieve the highest MB removal efficiency onto Mg-PKS biochar composite. It is observed that the combination of $\mathrm{pH} 10$ and contact time of $30 \mathrm{~min}$ with a fixed adsorbent dosage of $0.5 \mathrm{~g}$ gave the highest removal of $98.50 \%$. Figure $4 \mathrm{~b}$ described that adsorption took about $30 \mathrm{~min}$ to reach equilibrium with $0.5 \mathrm{~g}$ as adsorbent dosage. In contrast, Figure $4 \mathrm{c}$ revealed that when the combination of adsorbent dosage and $\mathrm{pH}$ conditions increased, high removal efficiency could be attained. The red regions on the graph plots indicate the highest removal of MB based on different parameters. The blue areas on the plots visualize the lowest removal efficiency of MB by Mg-PKS biochar composite. The optimization analysis recommends using a $\mathrm{pH}$ value of 10 , contact time of $30 \mathrm{~min}$, and adsorbent dosage of $0.5 \mathrm{~g}$ to achieve $100 \% \mathrm{MB}$ removal. The result is comparable with previous study whereby the optimized $\mathrm{pH}$ value was obtained at $\mathrm{pH} 9.5$ and dosage of $0.6 \mathrm{~g}$ by using maple biochar (Allouss et al., 2019). Another study using cellulose-based beads mentioned that maximum adsorption capacity for MB was obtained at higher $\mathrm{pH}$ (9-10) (Choi et al., 2020). However, Mousavi et al. (2017) showed that the best maximum adsorption was found to be at $\mathrm{pH} \mathrm{3}$, a dosage of $0.2 \mathrm{~g} / \mathrm{L}$ with a contact time of $10 \mathrm{~min}$. This result is the opposite of the current study, probably due to the type of adsorbent used, which is $N$. microphyllum activated carbon. 


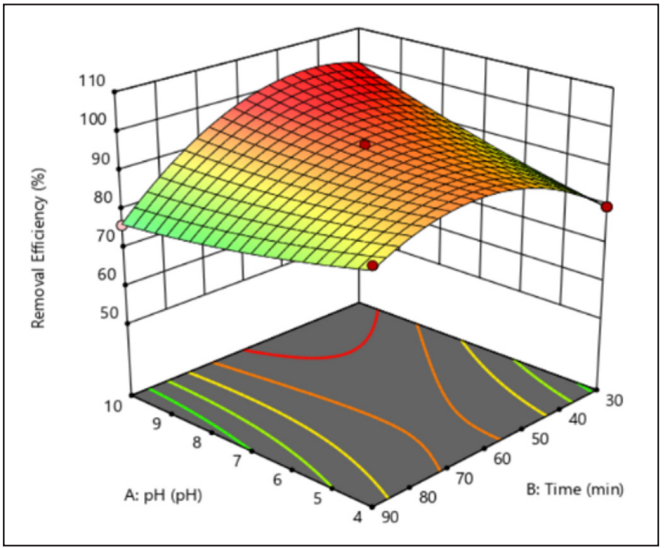

(a)

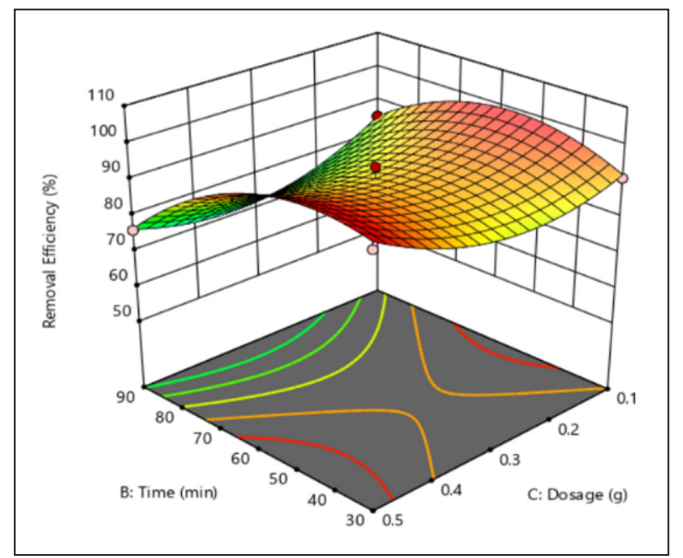

(b)

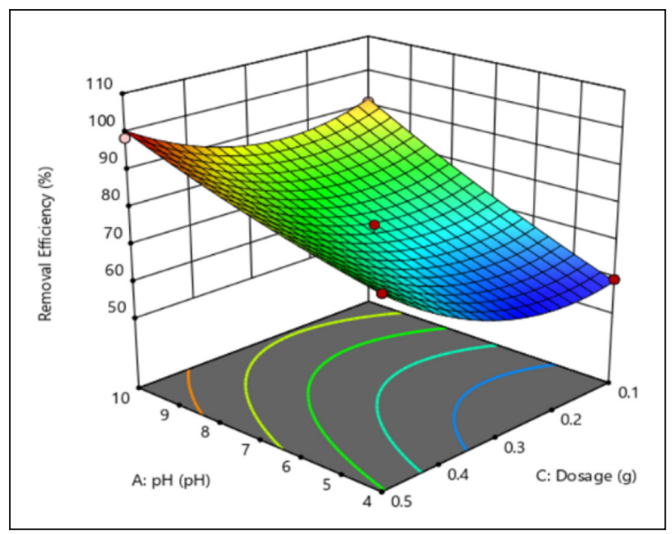

(c)

Figure 4. 3D response surface graph and contour plot showing the effect of (a) pH and time, (b) time and adsorbent dosage, and (c) $\mathrm{pH}$ and adsorbent dosage on $\mathrm{MB}$ removal efficiency by Mg-PKS biochar composite

\section{Validation Experiment}

The factors affecting the removal performance of MB by Mg PKS biochar were attained via Design-Expert software: The optimum combination of $\mathrm{pH}$, contact time and adsorbent dosage suggested by the software were $8.72,54.07 \mathrm{~min}$ and $0.2828 \mathrm{~g}$, respectively. Based on the RSM analysis, the predicted removal efficiency was $87.62 \%$. Validation experiments were conducted under the optimum parameters of $\mathrm{pH} 8.5$, contact time of $55 \mathrm{~min}$ and dosage of $0.3 \mathrm{~g}$. Table 8 is the results of validation experiments.

From the Table 8 , the actual experimental MB removal efficiency was found to be $84.97 \%$. The percentage deviation from the predicted value was $3.02 \%$, which means the error is small (Zhou et al., 2019). Thus, it can be concluded that the RSM model could predict the removal efficiency of MB by Mg-PKS biochar. 
Table 8

Validation experiment results under optimum parameters

\begin{tabular}{cccccc}
\hline & \multicolumn{3}{c}{ Parameters } & \multicolumn{2}{c}{ Mg-PKS biochar composite } \\
\hline Run & pH & Time (min) & Dosage $(\mathrm{g})$ & $\begin{array}{c}\text { Experimental MB removal } \\
\text { efficiency }(\%)\end{array}$ & $\begin{array}{c}\text { Predicted MB removal } \\
\text { efficiency (\%) }\end{array}$ \\
\hline 1 & 8.5 & 55 & 0.3 & 84.97 & 87.62 \\
\hline
\end{tabular}

\section{Biochar Properties Comparison}

Table 9 shows the comparison of the properties between steam activated PKS biochar and Mg-PKS biochar. Based on the characterization of both biochars, Mg-PKS biochar has a larger surface area of $674 \mathrm{~m}^{2} \mathrm{~g}^{-1}$ compared to steam activated PKS biochar $\left(592 \mathrm{~m}^{2} \mathrm{~g}^{-1}\right)$. Mg-PKS biochar also has a larger total pore volume of $0.424 \mathrm{~cm}^{3} \mathrm{~g}^{-1}$ than the total pore volume of steam activated PKS biochar, which is $0.353 \mathrm{~cm}^{3} \mathrm{~g}^{-1}$. Both biochars contained high carbon content. The carbon in the biochar can develop the carbons' structures into pores, indicating the potential enhancement of the sorption sites on the surface of the biochar (Liew et al., 2017). Mg-PKS biochar is porous as the adsorbent displayed high adsorption capacity. O-H groups are present in both biochars (Figure 2). However, Mg-PKS biochar composite managed to generate extra O-H groups, which facilitate the adsorption ability of Mg-PKS biochar (Zhao et al., 2018). The band spectra that representing the O-H group shifted to higher wavenumbers because of the increase in the interactions between the hydroxyl group of the biochar and MB (Komnitsas \& Zaharaki, 2016). Adsorption of contaminants from aqueous solution by adsorbents is caused by chemical interactions such as electrostatic interaction, cation exchange and surface precipitation (Sizmur et al., 2017).

Table 9

Comparison of the properties between steam activated PKS biochar and Mg-PKS biochar

\begin{tabular}{lcc}
\hline Properties & Steam activated PKS biochar & Mg-PKS biochar \\
\hline Specific surface area & $592 \mathrm{~m}^{2} \mathrm{~g}^{-1}$ & $674 \mathrm{~m}^{2} \mathrm{~g}^{-1}$ \\
Pore volume & $0.353 \mathrm{~cm}^{3} \mathrm{~g}^{-1}$ & $0.424 \mathrm{~cm}^{3} \mathrm{~g}^{-1}$ \\
Organic matter & $70.37 \%$ & $62.81 \%$ \\
Porosity & - & Porous \\
Functional groups & $\mathrm{O}-\mathrm{H}$ present & Extra O-H generated \\
Adsorption & - & Higher adsorption capacity \\
\hline
\end{tabular}

\section{CONCLUSION}

Mg-biochar composite developed from PKS biochar exhibits excellent adsorbent properties and high removal efficiency for MB in an aqueous solution. The Mg-PKS biochar composite has irregular shape pore structure, a surface area of $674 \mathrm{~m}^{2} \mathrm{~g}^{-1}$ and average pore diameters 
of $7.2195 \mu \mathrm{m}$. The optimum removal of MB onto Mg-PKS biochar composite was at $\mathrm{pH}$ 10,30 min contact time and $0.5 \mathrm{~g} / 100 \mathrm{~mL}$ dosage with a removal efficiency of $98.50 \%$. This study suggests the potential application of $\mathrm{Mg}$ treatment as an alternative to other chemical treatment for biochar upgrading to adsorbent for removing MB from water bodies.

\section{ACKNOWLEDGEMENT}

The authors thank the Ministry of Higher Education Malaysia and Universiti Malaysia Sarawak for funding this work (Fundamental Research Grant Scheme; Grant No.: F07/ FRGS/1494/2016).

\section{REFERENCES}

Albadarin, A. B., Collins, M. N., Naushad, M., Shirazian, S., \& Mangwandi, C. (2016). Activated lignin chitosan extruded blends for efficient adsorption of methylene blue. Chemical Engineering Journal, 307, 264-272. https://doi.org/10.1016/j.cej.2016.08.089

Alene, A. N., Abate, G. Y., \& Habte, A. T. (2020). Bioadsorption of basic blue dye from aqueous solution onto raw and modified waste ash as economical alternative bioadsorbent. Journal of Chemistry, 2020, Article 8746035. https://doi.org/10.1155/2020/8746035

Allouss, D., Essamlali, Y., Amadine, O., Chakir, A., \& Zahouily, M. (2019). Response surface methodology for optimization of methylene blue adsorption onto carboxymethyl. RSC Advances, 9, 37858-37869. https://doi.org/10.1039/c9ra06450h

Antunes, E., Jacob, M. V, Brodie, G., \& Schneider, P. A. (2017). Silver removal from aqueous solution by biochar produced from biosolids via microwave pyrolysis. Journal of Environmental Management, 203, 264-272. https://doi.org/10.1016/j.jenvman.2017.07.071

Ba, O. S., Ka, H., Shoe, T., Ya, H., \& Yo, N. (2020). Novel approach for effective removal of methylene blue dye from water using fava bean peel waste. Scientific Reports, 10, 1-10. https://doi.org/10.1038/s41598020-64727-5

Bendaho, D., Driss, T. A., \& Bassou, D. (2015). Removal of cationic dye methylene blue from aqueous solution by adsorption on Algerian clay. International Journal of Waste Resources, 5(1), 1-6. https://doi. org/10.4303/2252-5211.1000175

Carvalho Eufrásio Pinto, M., David Da Silva, D., Amorim Gomes, A. L., Menezes Dos Santos, R. M., Alves De Couto, R. A., Ferreira De Novais, R., Leopoldo Constantino, V. R., Tronto, J., \& Pinto, F. G. (2019). Biochar from carrot residues chemically modified with magnesium for removing phosphorus from aqueous solution. Journal of Cleaner Production, 222, 36-46. https://doi.org/10.1016/j.jclepro.2019.03.012

Choi, Y., Gurav, R., Kim, H. J., Yang, Y., \& Bhatia, S. K. (2020). Evaluation for simultaneous removal of anionic and cationic dyes onto maple leaf-derived biochar using response surface methodology. Applied Sciences, 10(9), Article 2982. https://doi.org/10.3390/app10092982

Fan, S., Tang, J., Wang, Y., Li, H., Zhang, H., Tang, J., Wang, Z., \& Li, X. (2016). Biochar prepared from copyrolysis of municipal sewage sludge and tea waste for the adsorption of methylene blue from aqueous 
solutions: Kinetics, isotherm, thermodynamic and mechanism. Journal of Molecular Liquids, 220, 432441. https://doi.org/10.1016/j.molliq.2016.04.107

Fang, C., Zhang, T., Li, P., Jiang, R. F., \& Wang, Y. C. (2014). Application of magnesium modified corn biochar for phosphorus removal and recovery from swine wastewater. International Journal of Environmental Research and Public Health, 11(9), 9217-9237. https://doi.org/10.3390/ijerph110909217

Fatiha, M., \& Belkacem, B. (2015). Adsorption of methylene blue from aqueous solutions using natural clay. Journal of Materials and Environmental Science, 3(5), 1-7. https://doi.org/10.4172/2157-7587.1000143

García, J. R., Sedran, U., Zaini, M. A. A., \& Zakaria, Z. A. (2018). Preparation, characterization, and dye removal study of activated carbon prepared from palm kernel shell. Environmental Science and Pollution Research, 25(6), 5076-5085. https://doi.org/10.1007/s11356-017-8975-8

Gnanasundaram, N., Loganathan, M., \& Singh, A. (2017). Optimization and performance parameters for adsorption of $\mathrm{Cr}^{6+}$ by microwave assisted carbon from Sterculia foetida shells. IOP Conference Series: Materials Science and Engineering, 206(1), 1-10. https://doi.org/10.1088/1757-899X/206/1/012065

Guarín, J. R., Moreno-Pirajan, J. C., \& Giraldo, L. (2018). Kinetic study of the bioadsorption of methylene blue on the surface of the biomass obtained from the Algae D. antarctica. Journal of Chemistry, 2018, Article 2124845. https://doi.org/10.1155/2018/2124845

Hasbullah, T. N. A. T., Selaman, O. S., \& Rosli, N. A. (2014). Removal of dye from aqeuous solutions using chemical activated carbon prepared from jackfruit (Artocarpus heterophyllus) peel waste. UNIMAS E-Journal of Civil Engineering, 5(1), 34-38.

He, R., Peng, Z., Lyu, H., Huang, H., Nan, Q., \& Tang, J. (2018). Synthesis and characterization of an ironimpregnated biochar for aqueous arsenic removal. Science of the Total Environment, 612, 1177-1186. https://doi.org/10.1016/j.scitotenv.2017.09.016

Jawad, A. H., Rashid, R. A., Ishak, M. A. M., \& Wilson, L. D. (2016). Adsorption of methylene blue onto activated carbon developed from biomass waste by $\mathrm{H} 2 \mathrm{SO} 4$ activation: Kinetic, equilibrium and thermodynamic studies. Desalination and Water Treatment, 57(52), 25194-25206. https://doi.org/10.10 80/19443994.2016.1144534

Jellali, S., Diamantopoulos, E., Haddad, K., Anane, M., Durner, W., \& Mlayah, A. (2016). Lead removal from aqueous solutions by raw sawdust and magnesium pretreated biochar : Experimental investigations and numerical modelling. Journal of Environmental Management, 180, 439-449. https://doi.org/10.1016/j. jenvman.2016.05.055

Jindo, K., Mizumoto, H., Sawada, Y., Sanchez-Monedero, M. A., \& Sonoki, T. (2014). Physical and chemical characterization of biochars derived from different agricultural residues. Biogeosciences, 11(23), 66136621. https://doi.org/10.5194/bg-11-6613-2014

Johari, K., Saman, N., Tien, S. S., Siew Chin, C., Kong, H., \& Mat, H. (2016). Removal of elemental mercury by coconut pith char adsorbents. Procedia Engineering, 148, 1357-1362. https://doi.org/10.1016/j. proeng.2016.06.588

Jung, K., \& Ahn, K. (2015). Fabrication of porosity-enhanced MgO/biochar for removal of phosphate from aqueous solution : Application of a novel combined electrochemical modification method. Bioresource Technology, 200, 1029-1032. https://doi.org/10.1016/j.biortech.2015.10.008 
Karaer, H., \& Kaya, I. (2016). Synthesis, characterization of magnetic chitosan/active charcoal composite and using at the adsorption of methylene blue and reactive blue. Microporous and Mesoporous Materials, 232, 26-38. https://doi.org/10.1016/j.micromeso.2016.06.006

Kim, H. (2014). Analysis of variance (ANOVA) comparing means of more than two groups. Restorative Dentistry and Endodontics, 7658, 74-77. https://doi.org/10.5395/rde.2014.39.1.74

Komnitsas, K. A., \& Zaharaki, D. (2016). Morphology of modified biochar and its potential for phenol removal from aqueous solutions. Frontiers in Environmental Science, 4(April), 1-11. https://doi.org/10.3389/ fenvs.2016.00026

Kuang, Y., Zhang, X., \& Zhou, S. (2020). Adsorption of methylene blue in water onto activated carbon by surfactant modification. Water, 12, 1-19. https://doi.org/10.3390/w12020587

Lam, S. S., Liew, R. K., Cheng, C. K., Rasit, N., Ooi, C. K., Ma, N. L., Ng, J. H., Lam, W. H., Chong, C. T., \& Chase, H. A. (2018). Pyrolysis production of fruit peel biochar for potential use in treatment of palm oil mill effluent. Journal of Environmental Management, 213, 400-408. https://doi.org/10.1016/j. jenvman.2018.02.092

Liao, P., Zhan, Z., Dai, J., Wu, X., Zhang, W., Wang, K., \& Yuan, S. (2013). Adsorption of tetracycline and chloramphenicol in aqueous solutions by bamboo charcoal: A batch and fixed-bed column study. Chemical Engineering Journal, 228, 496-505. https://doi.org/10.1016/j.cej.2013.04.118

Liew, R. K., Nam, W. L., Chong, M. Y., Phang, X. Y., Su, M. H., Yek, P. N. Y., Ma, N. L., Cheng, C. K., Chong, C. T., \& Lam, S. S. (2017). Oil palm waste: An abundant and promising feedstock for microwave pyrolysis conversion into good quality biochar with potential multi-applications. Process Safety and Environmental Protection, 115, 57-69. https://doi.org/10.1016/j.psep.2017.10.005

Liu, W. J., Jiang, H., \& Yu, H. Q. (2015). Development of biochar-Based functional materials: toward a sustainable platform carbon material. Chemical Reviews, 115(22), 12251-12285. https://doi.org/10.1021/ acs.chemrev.5b00195

Liu, Z., \& Han, G. (2015). Production of solid fuel biochar from waste biomass by low temperature pyrolysis. Fuel, 158, 159-165. https://doi.org/10.1016/j.fuel.2015.05.032

Mahmood, W. M. F. W., Ariffin, M. A., Harun, Z., Ghani, J. A., Ishak, N. A. I. M., \& Rahman, M. N. A. (2015). Characterisation and potential use of biochar from gasified oil palm wastes. Journal of Engineering Science and Technology, 10(2014), 45-54. https://www.researchgate.net/publication/287534129_Characterisation_ and_potential_use_of_biochar_from_gasified_oil_palm_wastes

Mahmoudi, K., Hamdi, N., \& Srasra, E. (2015). Study of adsorption of methylene blue onto activated carbon from lignite. Surface Engineering and Applied Electrochemistry, 51(5), 427-433. https://doi.org/10.3103/ S1068375515050105

Marrakchi, F., Ahmed, M. J., Khanday, W. A., Asif, M., \& Hameed, B. H. (2017). Mesoporous-activated carbon prepared from chitosan flakes via single-step sodium hydroxide activation for the adsorption of methylene blue. International Journal of Biological Macromolecules, 98, 233-239. https://doi. org/10.1016/j.ijbiomac.2017.01.119 
Mousavi, S. A., Mehralian, M., Khashij, M., \& Parvaneh, S. (2017). Methylene blue removal from aqueous solutions by activated carbon prepared from N. Microphyllum (AC-NM): RSM analysis, isotherms and kinetic studies. Global Nest Journal, 19(4), 697-705.

Niran, O. B., Olawale, S. A., \& Ushie, U. J. (2018). Isotherm studies of adsorption of methylene blue by palm kernel shell. Asian Journal of Applied Chemistry Research, 1(1), 1-9. https://doi.org/10.9734/ AJACR/2018/41300

Ocholi, O. J., Gimba, C. E., Ndukwe, G. I., Turoti, M., Abechi, S. E., \& Edogbanya, P. R. O. (2016). Effect of time on the adsorption of methylene blue, methyl orange and indigo carmine onto activated carbon. IOSR Journal of Applied Chemistry, 9(9), 55-62. https://doi.org/10.9790/5736-0909015562

Ozturk, D., \& Sahan, T. (2015). Design and optimization of Cu ( II ) adsorption conditions from aqueous solutions by low-cost adsorbent pumice with response surface methodology. Polish Journal of Environmental Studies, 24(4), 1749-1756. https://doi.org/10.15244/pjoes/40270

Pandimurugan, R., \& Thambidurai, S. (2016). Synthesis of seaweed-ZnO-PANI hybrid composite for adsorption of methylene blue dye. Biochemical Pharmacology, 4(1), 1332-1347. https://doi.org/10.1016/j. jece.2016.01.030

Pang, J., Fu, F., Ding, Z., Lu, J., Li, N., \& Tang, B. (2017). Adsorption behaviors of methylene blue from aqueous solution on mesoporous birnessite. Journal of the Taiwan Institute of Chemical Engineers, 77, 168-176. https://doi.org/10.1016/j.jtice.2017.04.041

Patel, B., \& Gami, B. (2012). Biomass characterization and its use as solid fuel for combustion. Iranica Journal of Energy \& Environment, 3(2), 123-128. https://doi.org/10.5829/idosi.ijee.2012.03.02.0071

Pathania, D., Sharma, S., \& Singh, P. (2017). Removal of methylene blue by adsorption onto activated carbon developed from Ficus carica bast. Arabian Journal of Chemistry, 10, 1445-1451. https://doi.org/10.1016/j. arabjc.2013.04.021

Pinto, M. D. C. E., da Silva, D. D., Gomes, A. L. A., dos Santos, R. M. M., de Couto, R. A. A., de Novais, R. F., Constantino, V. R. L., Tronto, J., \& Pinto, F. G. (2019). Biochar from carrot residues chemically modified with magnesium for removing phosphorus from aqueous solution. Journal of Cleaner Production, 222, 36-46. https://doi.org/10.1016/j.jclepro.2019.03.012

Rajapaksha, A. U., Chen, S. S., Tsang, D. C. W., Zhang, M., Vithanage, M., Mandal, S., Gao, B., Bolan, N. S., \& Ok, Y. S. (2016). Engineered/designer biochar for contaminant removal/immobilization from soil and water: Potential and implication of biochar modification. Chemosphere, 148(October), 276-291. https:// doi.org/10.1016/j.chemosphere.2016.01.043

Riddle, M., Bergström, L., Schmieder, F., Lundberg, D., Condron, L., \& Cederlund, H. (2019). Impact of biochar coated with magnesium (hydr)oxide on phosphorus leaching from organic and mineral soils. Journal of Soils and Sediments, 19(4), 1875-1889. https://doi.org/10.1007/s11368-018-2197-7

Rout, T., Pradhan, D., Singh, R. K., \& Kumari, N. (2016). Exhaustive study of products obtained from coconut shell pyrolysis. Journal of Environmental Chemical Engineering, 4(3), 3696-3705. https://doi. org/10.1016/j.jece.2016.02.024 
Rugayah, A. F., Astimar, A. A., \& Norzita, N. (2014). Preparation and characterisation of activated carbon from palm kernel shell by physical activation with steam. Journal of Oil Palm Research, 26(3), 251-264.

Sahu, S., Pahi, S., Tripathy, S., Singh, S. K., Behera, A., Sahu, U. K., \& Patel, R. K. (2020). Adsorption of methylene blue on chemically modified lychee seed biochar: dynamic, equilibrium, and thermodynamic study. Journal of Molecular Liquids, 315, Article 113743. https://doi.org/10.1016/j.molliq.2020.113743

Sarkar, D. (2015). Fuels and combustion. In Thermal power plant (pp. 91-137). Elsevier. https://doi.org/10.1016/ B978-0-12-801575-9.00003-2

Sartape, A., Mandhare, A., Salvi, P., Pawar, D., Raut, P., Anuse, M., \& Kolekar, S. (2012). Removal of Bi (III) with adsorption technique using coconut shell activated carbon. Chinese Journal of Chemical Engineering, 20(4), 768-775. https://doi.org/10.1016/S1004-9541(11)60247-4

Shen, Z., Zhang, J., Hou, D., Tsang, D. C. W., Ok, Y. S., \& Alessi, D. S. (2018). Synthesis of MgO-coated corncob biochar and its application in lead stabilization in a soil washing residue. Environment International, 122, 357-362. https://doi.org/10.1016/j.envint.2018.11.045

Sizmur, T., Fresno, T., Akgül, G., Frost, H., \& Moreno, E. (2017). Biochar modification to enhance sorption of inorganics from water. Bioresource Technology, 246, 34-47. https://doi.org/10.1016/j.biortech.2017.07.082

Stat-Ease. (2021). Response surface. Retrieved December 03, 2019, from https://www.statease.com/docs/ v11/tutorials/multifactor-rsm/

Tan, X., Liu, Y., Zeng, G., Wang, X., Hu, X., Gu, Y., \& Yang, Z. (2015). Application of biochar for the removal of pollutants from aqueous solutions. Chemosphere, 125, 70-85. https://doi.org/10.1016/j. chemosphere.2014.12.058

Tang, R., Dai, C., Li, C., Liu, W., Gao, S., \& Wang, C. (2017). Removal of methylene blue from aqueous solution using agricultural residue walnut shell: Equilibrium, kinetic, and thermodynamic studies. Journal of Chemistry, 2017, 1-10. https://doi.org/10.1155/2017/8404965

Thakkar, A., \& Saraf, M. (2014). Application of statistically based experimental designs to optimize cellulase production and identification of gene. Natural Products and Bioprospecting, 4, 341-351. https://doi. org/10.1007/s13659-014-0046-y

Tripathi, M., Sahu, J. N., \& Ganesan, P. (2016). Effect of process parameters on production of biochar from biomass waste through pyrolysis: A review. Renewable and Sustainable Energy Reviews, 55, 467-481. https://doi.org/10.1016/j.rser.2015.10.122

Wahi, R., Aziz, S. M. A., Hamdan, S., \& Ngaini, Z. (2015). Biochar production from agricultural wastes via low-temperature microwave carbonization. In 2015 IEEE international RF and microwave conference (RFM) (pp. 244-247). IEEE Conference Publication. https://doi.org/10.1109/RFM.2015.7587754

Wahi, R., Chuah, L. A., Ngaini, Z., Nourouzi, M. M., \& Choong, T. S. Y. (2014). Esterification of M. sagu bark as an adsorbent for removal of emulsified oil. Journal of Environmental Chemical Engineering, 2(1), 324-331. https://doi.org/10.1016/j.jece.2013.12.010

Wu, Z., Zhong, H., Yuan, X., Wang, H., Wang, L., Chen, X., Zeng, G., \& Wu, Y. (2014). Adsorptive removal of methylene blue by rhamnolipid-functionalized graphene oxide from wastewater. Water Research, 67, 330-344. https://doi.org/10.1016/j.watres.2014.09.026 
Xue-jiao, C., Qi-mei, L. I. N., Rizwan, M., Xiao-rong, Z., \& Gui-tong, L. I. (2019). Steam explosion of crop straws improves the characteristics of biochar as a soil amendment. Journal of Integrative Agriculture, 18(7), 1486-1495. https://doi.org/10.1016/S2095-3119(19)62573-6

Zhang, M., Gao, B., Yao, Y., Xue, Y., \& Inyang, M. (2012). Synthesis of porous MgO-biochar nanocomposites for removal of phosphate and nitrate from aqueous solutions. Chemical Engineering Journal, 210, $26-32$. https://doi.org/10.1016/j.cej.2012.08.052

Zhao, X., Yi, S., Dong, S., Xu, H., Sun, Y., \& Hu, X. (2018). Removal of Levofloxacin from aqueous solution by Magnesium-impregnated Biochar: Batch and column experiments. Chemical Speciation and Bioavailability, 30(1), 68-75. https://doi.org/10.1080/09542299.2018.1487775

Zhou, R., Zhang, M., Zhou, J., \& Wang, J. (2019). Optimization of biochar preparation from the stem of Eichhornia crassipes using response surface methodology on adsorption of Cd2+. Scientific Reports, 9 , 1-17. https://doi.org/10.1038/s41598-019-54105-1

Zhu, S., Fang, S., Huo, M., Yu, Y., Chen, Y., Yang, X., \& Geng, Z. (2015). A novel conversion of the groundwater treatment sludge to magnetic particles for the adsorption of methylene blue. Journal of Hazardous Materials, 292, 173-179. https://doi.org/10.1016/j.jhazmat.2015.03.028 
